\title{
PERHUTANAN SOSIAL BAGI AKSES KEADILAN MASYARAKAT DAN PENGURANGAN KEMISKINAN
}

\section{SOCIAL FORESTRY FOR COMMUNITY JUSTICE ACCESS AND POVERTY REDUCTION}

\author{
Hani Afnita Murti \\ Kementerian Lingkungan Hidup dan Kehutanan
}

\begin{abstract}
Abstrak
Kemiskinan bukan hanya dimaknai sebagai persoalan deprivasi ekonomi semata, namun menyentuh krisis multidimensi. Masyarakat sekitar hutan merupakan salah satu kelompok miskin terbesar di Indonesia. Sekitar 48,8 juta orang tinggal pada lahan hutan negara dan sekitar 10,2 juta diantaranya dikategorikan miskin dimana 71,06\% menggantungkan hidupnya dari sumber daya hutan. Kondisi sosial ekonomi ini ditambah sulitnya masyarakat dalam mengakses hutan sering memercikkan dan menyalakan konflik kawasan hutan (konflik tenurial). Kebanyakan masyarakat sekitar hutan tidak memiliki perlindungan hukum baik terhadap legalitas maupun akses sumber daya hutan. Kebijakan Perhutanan Sosial muncul sebagai salah satu elemen dari reforma agraria, yang merupakan kebijakan yang digulirkan pemerintah untuk memastikan legalitas aset dan redistribusi tanah yang dikenal dengan kebijakan TORA (Tanah Objek Reforma Agraria), serta memastikan legalitas akses melalui kebijakan Perhutanan Sosial. Terdapat nexus yang menunjukkan korelasi positif yang diklaim oleh pemerintah bahwa kebijakan Perhutanan Sosial mampu menjadi alternatif kebijakan pengurangan angka kemiskinan. Perhutanan Sosial yang dilaksanakan secara klaster pada akhirnya akan menumbuhkan pusat ekonomi domestik sehingga kesempatan kerja terbuka luas dan penurunan kemiskinan akan signifikan. Keberadaan skema Perhutanan Sosial telah menjadi bagian integral dari pembangunan desa, pengentasan warga miskin, sekaligus membangun kemandirian sosial-ekonomi warga miskin di dalam dan sekitar hutan. Data rasio gini menunjukkan bahwa rasio gini tahun 2018 menunjukkan nilai lebih rendah yaitu 0,389 dari tahun 2017 sebesar 0,391. Sedangkan jumlah penduduk miskin juga berkurang menjadi 9,82\% di tahun 2018 dibandingkan tahun 2017 sebesar 10,12\%.
\end{abstract}

Kata Kunci: kemiskinan, hutan, masyarakat kawasan hutan, perhutanan sosial.

\begin{abstract}
Poverty is not only interpreted as a matter of mere economic deprivation, but it touches a multidimensional crisis. The surrounding forest community is one of the largest poor groups in Indonesia. About 48.8 million people live on state forest land and around 10.2 million of them are categorized as poor where $71.06 \%$ depend on forest resources. These socio-economic conditions coupled with the difficulty of communities in accessing forests often sprinkle and ignite forest area conflicts (tenure conflicts). Most communities around the forest do not have legal protection for both legality and access to forest resources. Social Forestry Policy emerged as one of the elements of agrarian reform, which is a policy initiated by the government to ensure asset legality and redistribution of land known as the TORA (Land Object of Agrarian Reform) policy, as well as ensuring legality of access through Social Forestry policies. There is nexus which shows a positive correlation claimed by the government that the Social Forestry policy is able to become an alternative poverty reduction policy. Social Forestry implemented in a cluster will eventually grow the center of the domestic economy so
\end{abstract}


that open employment opportunities and a reduction in poverty will be significant. The existence of the Social Forestry scheme has become an integral part of village development, alleviation of the poor, while building the socio-economic independence of the poor in and around the forest. The gini ratio data shows that the gini ratio in 2018 shows a lower value of 0.389 from 2017 at 0.391. While the number of poor people also decreased to $9.82 \%$ in 2018 compared to 2017 at $10.12 \%$.

Keywords : poverty, forests, community forest areas, social forestry.

\section{A. Pendahuluan}

Hutan dengan berbagai sumber daya melimpahnya menjadi sumber pemenuhan ekonomi bagi masyarakat sekitar hutan untuk kebutuhan hidupnya. Hutan menyediakan pelayanan ekosistem yang mendasar bagi penghidupan dan kesejahteraan masyarakat sekitar hutan. Hutan dan kehutanan memainkan peranan penting dalam upaya pengentasan kemiskinan dengan menaikkan pendapatan, meningkatkan keamanan pangan, mengurangi kerentanan, dan memperbaiki kelestarian sumberdaya alam yang memberikan kontribusi terhadap peningkatan kesejahteraan masyarakat (Warner, 2000). Namun kenyataannya kemiskinan masyarakat yang tinggal di sekitar hutan maupun masyarakat yang telah memiliki kearifan lokal (hutan adat) justru banyak didapatkan. Sekitar 48,8 juta orang tinggal pada lahan hutan negara dan sekitar 10,2 juta di antaranya dianggap miskin (Brown, 2004). Setidaknya terdapat 10,2 juta orang miskin dalam kawasan hutan yang tidak memiliki aspek legal terhadap sumber daya hutan. ${ }^{7}$ Selain itu ada 20 juta orang yang tinggal di desa-desa dekat hutan dan enam juta orang di antaranya memperoleh sebagian besar penghidupannya dari hutan (Sunderlin, et al. 2000). Pada saat yang sama, terdapat jutaan hektar lahan rusak yang sebenarnya dapat dialih fungsikan untuk penggunaan yang lebih produktif agar bermanfaat bagi perekonomian dan penduduk miskin. Memberi perhatian pada hutan dan masyarakat di kawasan hutan mutlak

${ }^{7}$ https://polkam.go.id/atasi-kemiskinanmasyarakat-sekitar-kawasan-hutan-presiden- diperlukan dalam mengupayakan penanggulangan kemiskinan di Indonesia.

Konflik tenurial yang terjadi di kawasan hutan adalah persoalan yang sangat kompleks yang dihadapi oleh Perhutani. Timbulnya konflik tenurial yang terjadi merupakan sebuah akibat dari benturan-benturan kepentingan yang terjadi dari berbagai pihak. Tekanan sosial yang semakin meningkat serta dinamika sosial politik di masyarakat memberikan dampak negatif terhadap eksistensi kawasan hutan. Pengakuan akan hak-hak masyarakat hutan adat dan teta kelolanya, menjadi perkerjaan Pemerintah untuk memenuhi kebijakan yang berpihak pada kepentingan mensejahterakan masyarakatnya. Jaminan akses keadilan menjadi tuntutan dan tantangan bagi pemerintah untuk menyelesaikan konflik tenurial yang terjadi. Pola-pola pendekatan dengan partisipasi masyarakat, penyediaan payung hukum untuk memenuhi rasa keadilan, dan keterbukaan informasi publik menjadi kunci keberhasilan untuk diterapkan dalam penyelesaian masalah konflik tenurial maupun peningkatan kesejateraan masyarakat Kawasan hutan.

Pada agenda global Sustainable Development Goals (SDGs) sebagai kelanjutan dari Millenium Development Goals (MDGs), kaitannya dengan kemiskinan, tertuang dalam poin pertama yaitu "No Poverty", artinya, pada tataran lokal, wajib diupayakan pengentasan kemiskinan yang tentu saja bersifat inklusif dan berkelanjutan. Terkait pengelolaan

jokowi-permudah-akses-perhutanan-sosiall Diakses pada tanggal 4 Desember 2018 
hutan dan peningkatan kesejahteraan masyarakat yang menggantungkan ekonominya dari hutan, respon pemerintah sudah ditunjukkan melalui perubahan paradigma pembangunan kehutanan yang dahulu berbasis pada state based centered atau pembangunan kehutanan yang benarbenar dikendalikan oleh pemerintah dan hanya berbasis kayu menuju pada paradigma community based forest management (Awang, 2007). Memajukan mata pencaharian masyarakat dan mengurangi kemiskinan merupakan salah satu tujuan utama pemanfaatan dan pengelolaan hutan di Indonesia. UndangUndang nomor 41 tahun 1999 tentang kehutanan mewajibkan bahwa hutan harus dikelola untuk dapat memberikan manfaat ganda kepada banyak pihak dan untuk kesejahteraan rakyat. Masalah lahan, mata pencaharian dan kemiskinan begitu penting dalam diskusi reformasi kebijakan yang sedang berjalan dan tata kelola di Indonesia.

Perhutanan Sosial menjadi agenda yang digenjot pemerintah yang diharapkan juga mengurangi kemiskinan dan konflik terkait dengan hak/akses terhadap lahan. Praktik Perhutanan Sosial penting dalam perbaikan kehidupan masyarakat miskin, menunjang pembangunan daerah dan kelangsungan sumber daya hutan itu sendiri, termasuk juga dalam konteks perubahan iklim. Program pemerintah tentang reforma agraria dan Perhutanan Sosial merupakan program koreksi yang progresif bagi kepentingan rakyat petani di Indonesia. Terdapat empat target yang ingin dicapai oleh kedua program yaitu memberikan pemerataan kepemilikan tanah melalui reforma agrarian, pemerataan dan perluasan pemanfaatan lahan hutan oleh masyarakat melalui Perhutanan Sosial, memperbaiki tata lingkungan, dan pengurangan kemiskinan di perdesaan. Kebijakan tersebut menguatkan pembangunan pedesaan di dalam dan di sekitar hutan untuk memberikan jaminan hak masyarakat desa untuk mengelola
Sumber Daya Alam (SDA) skala lokal mendukung pegentasan desa tertinggal dan pengembangan desa mandiri.

Perhutanan Sosial yang dikatakan sebagai legalisasi deforestasi (referensi) tentu tidaklah tepat dan ahistoris. Yang justru sebaliknya, Perhutanan Sosial merupakan upaya legal reforestasi dengan masyarakat sebagai pelaku utama yang dalam artian telah mengkulturisasikan pendekatan community based forest management. Beberapa kendala mengiringi implementasi kebijakan Perhutanan Sosial ini, namun hasil positif yang muncul bisa diperhatikan oleh pemerintah hingga menjadi model pemberantasan kemiskinan di dalam dan sekitar hutan yang berdaya guna dan berhasil guna, baik melindungi ekosistem dan pemanfaatan hutan yang berkelanjutan, serta mensejahterakan masyarakat di kawasan hutan. Kaitan lingkungan (termasuk hutan) dan kemiskinan perlu dipertimbangkan, dianalisis, dan di evaluasi dalam mendiagnosa kemiskinan guna penentuan tindakan yang paling tepat.

Berdasarkan latar belakang tersebut, maka akan diuraikan bagaimana hasil kebijakan Perhutanan Sosial yang mampu memberikan nexus yang positif terhadap peningkatan kesejahteraan masyarakat Kawasan hutan, yang pada akhirnya berimbas pada pengurangan angka kemiskinan di Indonesia.

\section{B. Potret Kemiskinan Masyarakat Sekitar Hutan}

Penduduk miskin pedesaan mempunyai banyak aset mata pencaharian, termasuk keterikatan sosial, sumberdaya fisik, kelembagaan tradisional, dan lahan serta alam. Masyarakat sekitar hutan adalah masyarakat yang secara umum lebih berkekurangan, baik dalam hal ekonomi, maupun wawasannya. Posisi dilematis di satu sisi merupakan masyarakat yang paling berperan dan bersentuhan langsung 
dalam konteks pelestarian hutan, sebaliknya di sisi digolongkan rata-rata miskin dan sangat membutuhkan penopang untuk memenuhi beragam kebutuhan hidupnya. Akses terhadap hutan yang kurang dan bahkan sering dikatakan melakukan aktivitas illegal memicu dan merebakkan konflik dari waktu ke waktu. Hak pemilikan dan pemanfaatan lahan oleh masyarakat seringkali tidak diakui, atau aturannya sendiri mungkin berlawanan atau tidak sesuai. Hal ini menunjukkan bahwa akses terhadap lahan di kawasan hutan merupakan permasalahan kronis yang berpotensi gawat.

Pada tahun 2004, sekitar 16\% penduduk Indonesia berada dalam keadaan miskin, dua pertiga penduduk miskin ini hidup di daerah pedesaan dan 48 juta hidup di dalam kawasan hutan yang diklaim negara (www.worldagroforestry.org). Sunderlin dkk (2005) mencatat bahwa "kemiskinan pedesaan yang sangat parah dan sisa hutan alam di negara-negara berkembang cenderung menempati ruang yang tumpang tindih". Sedangkan berdasar data Kementerian Kehutanan tahun 2006 tercatat sekitar 48,8 juta jiwa atau $12 \%$ dari 219,9 juta jiwa penduduk Indonesia tinggal di dalam dan sekitar hutan. Dari 48,8 juta jiwa penduduk yang tinggal di dalam dan sekitar hutan tersebut 10,2 juta jiwa atau $25 \%$ diantaranya tergolong dalam kategori miskin, termasuk di dalamnya 1,6 juta kepala keluarga yang berada di lebih 12 ribu desa yang tinggal di sekitar hutan konservasi.

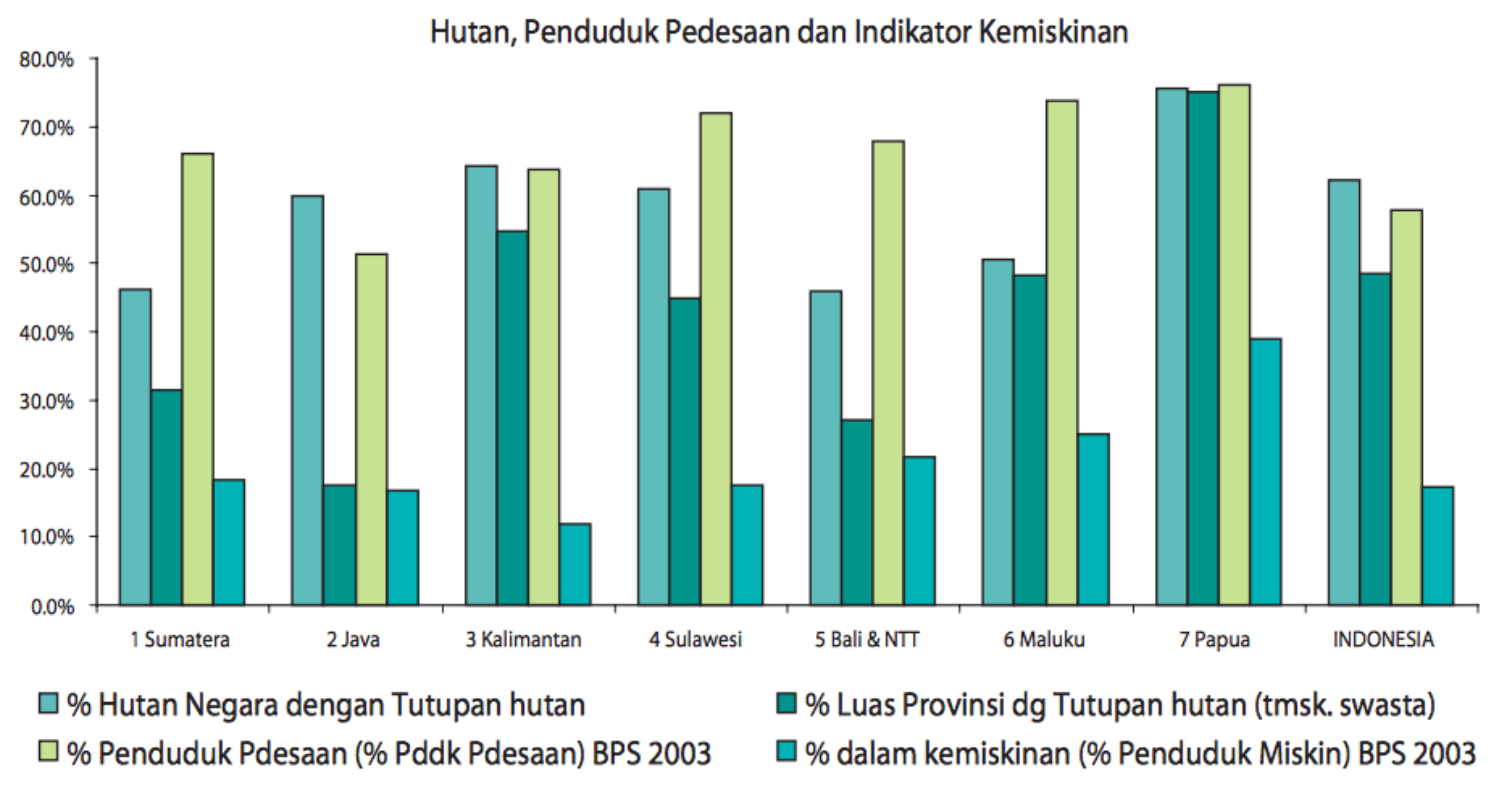

Gambar 1. Persentase penduduk miskin menurut pulau (BPS, 2003) 


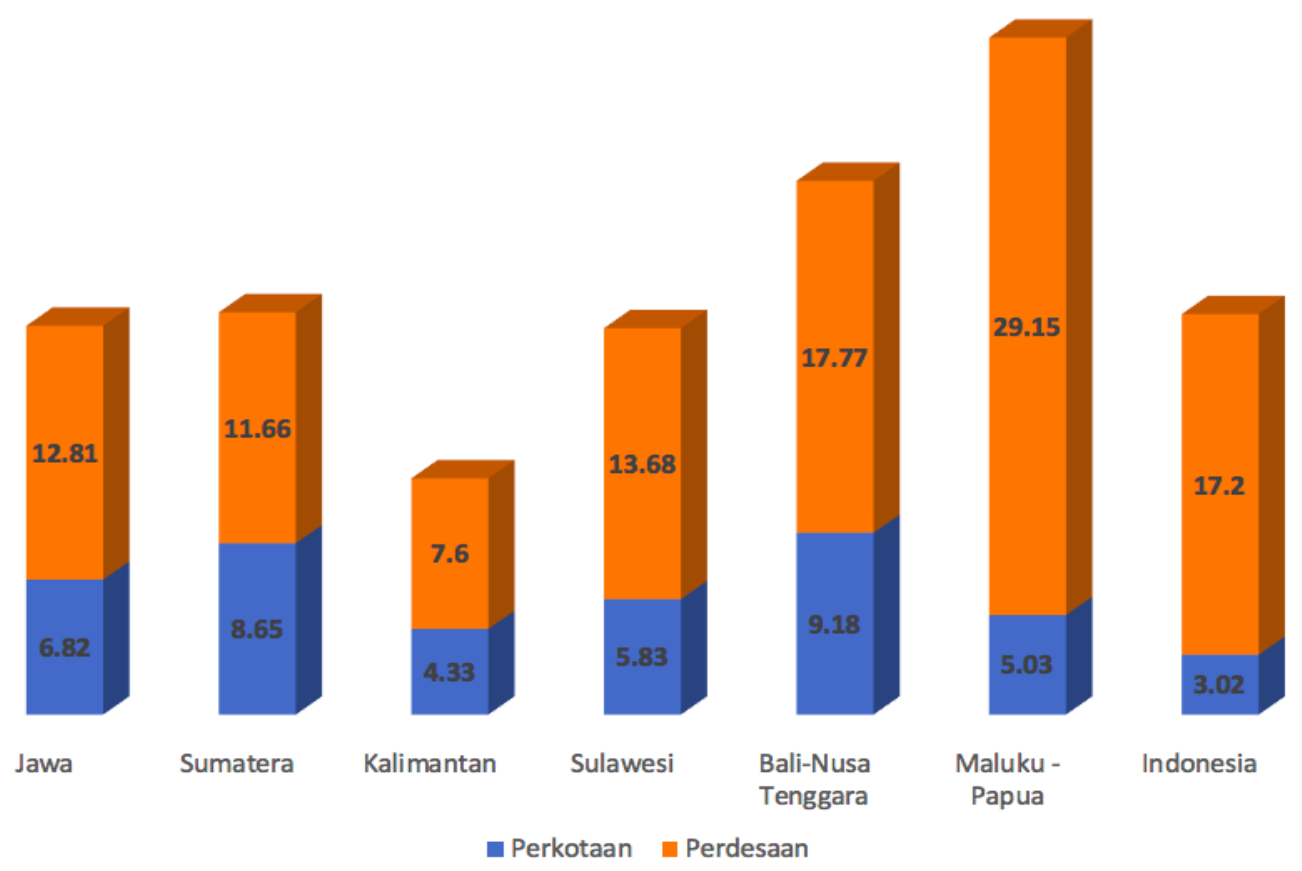

Gambar 2. Persentase penduduk miskin menurut pulau (BPS, 2018)

Data Badan Pusat Statistik (BPS) menunjukkan (Gambar 1 dan Gambar 2) kejadian kemiskinan tertinggi terdapat di pulau-pulau sebelah Timur, khususnya di Papua, yang tetap masih memiliki tutupan hutan yang besar. Angka penduduk miskin tertinggi berada di sebelah Barat, terutama di pulau Jawa, yang memiliki porsi terendah sisa tutupan hutannya dibandingkan dengan semua pulau besar. Ketimpangan inilah yang menjadi tantangan yang harus dijawab oleh Pemerintah kaitannya dengan kesejahteraan masyarakat di kawasan hutan.

\section{Skema Perhutanan Sosial}

Dalam konteks kebijakan pengelolaan hutan di Indonesia, kebijakan kehutanan yang dapat dikaitkan atau dikatakan sebagai model Perhutanan Sosial setidaknya sudah mulai sejak 1972, dalam bentuk program-program prosperity approach Perhutani yang makin

http://www.mongabay.co.id/2018/07/30/perhu tanan-sosial-dorong-reforestasi-bukan- terlembaga dalam program Perhutanan Sosial pada 1980-an atas dukungan Ford Foundation ${ }^{8}$. Sesuai Peraturan Menteri Lingkungan Hidup dan Kehutanan Nomor 83 Tahun 2016 tentang Perhutanan Sosial, pemerintah memberi akses legal kepada masyarakat di dalam dan sekitar hutan atau masyarakat hukum adat untuk mengelola hutan secara lestari melalui lima skema tematik (hutan desa (HD), hutan kemasyarakatan (HKm), hutan tanaman rakyat (HTR), hutan rakyat (HR), hutan adat (HA) dan kemitraan kehutanan) dan satu skema spasial melalui PIAPS (Peta Indikatif Areal Perhutanan Sosial). Terdapat 5 (lima) pola Perhutanan Sosial yang digulirkan pemerintah meliputi agroforestry, agro fishery, agro silvo pastural, jasa lingkungan (ekowisata), dan hasil hutan non kayu. Sedangkan strategi pengelolaan sumber daya alam (SDA) melalui Perhutanan Sosial melalui Social Security Net dan Sustainable Livelihood and Landscape. Realisasi program Perhutanan Sosial sampai dengan

legalisasi-deforestasi/ Diakses pada tanggal 4 Desember 2018 
November 2018 adalah seluas 2,13 juta Ha atau $16,8 \%$ dari total target sebesar 12,7 juta Ha (Perhutani, 2018).

Pemerintah melalui Kementerian Lingkugan Hidup dan Kehutanan (KLHK) telah menyiapkan luas alokasi Arahan Pemanfaatan Hutan Produksi yang Tidak Dibebani Izin untuk Perhutanan Sosial (HKm, HD, HTR ) seluas $\pm 6,98$ juta ha. Juga mewujudkan Perhutanan Sosial melalui kemitraan dengan IUPHHK-HTI dengan luas kemitraan 124.240 hektar pada tahun 2017 telah menjadi 185.160 hektar pada tahun 2018 dengan pelibatan masyarakat dari $35.311 \mathrm{KK}$ menjadi 46.289 KK. Pada tahun 2019 direncanakan menambah luas kemitraan menjadi 277.520 ha dengan melibatkan 69.381 KK (Ditjen PHPL, 2018). Dalam Kawasan konservasi terdapat total 6.381 desa disekitar kawasan konservasi, dengan open area seluas open area 2.235.827 Ha dan 1.645.155 Ha luas total usulan wilayah adat dalam hutan konservasi, pemerintah telah mengusulkan area Perhutanan Sosial lokasi yang terdapat open area, sedangkan penetapan hutan adat harus melalui verifikasi terlebih dahulu (Ditjen KSDAE, 2018). Pemerintah juga menyediakan kebun bibit yang dikelola oleh kelompok masyarakat peserta IPHPS baik laki-laki maupun perempuan melalui pembuatan bibit berbagai jenis tanaman hutan penghasil kayu maupun hasil hutan bukan kayu (HHBK) dan/atau tanaman multi purpose tree species (MPTS), yang pembiayaannya bersumber dari dana pemerintah, berada di dalam kawasan hutan di areal ijin pemanfaatan hutan Perhutanan Sosial (IPHPS) dalam areal kerja perum perhutani (Ditjen PDASHL, 2018). Selain itu terdapat pendampingan Perhutanan Sosial melalui skema "berteman" yaitu pendampingan yang berbagi peran, menerapkan kebersamaan dan membangun Kelompok Tani Hutan (KTH) menjadi KTH yang mandiri antar PK-PNS, PKSM, LSM, Perguruan Tinggi, dunia usaha, dan lain-lain yang ditujukan untuk penguatan KTH dalam melalui pendekatan kelola kelembagaan, kelola kawasan, dan kelola usaha. Pendampingan meliputi hal yang bersifat teknis, seperti teknik budidaya tanaman, penanggulangan hama tanaman, sampai dengan aspek softskill, seperti tata niaga hasil hutan, enterpreneurship, manajemen keuangan, dan tata persuratan serta birokrasi (BP2SDM, 2018). Pada tahun 2019, skema Perhutanan Sosial yang ditargetkan pemerintah yaitu 2.540 .000 ha (Gambar 3).

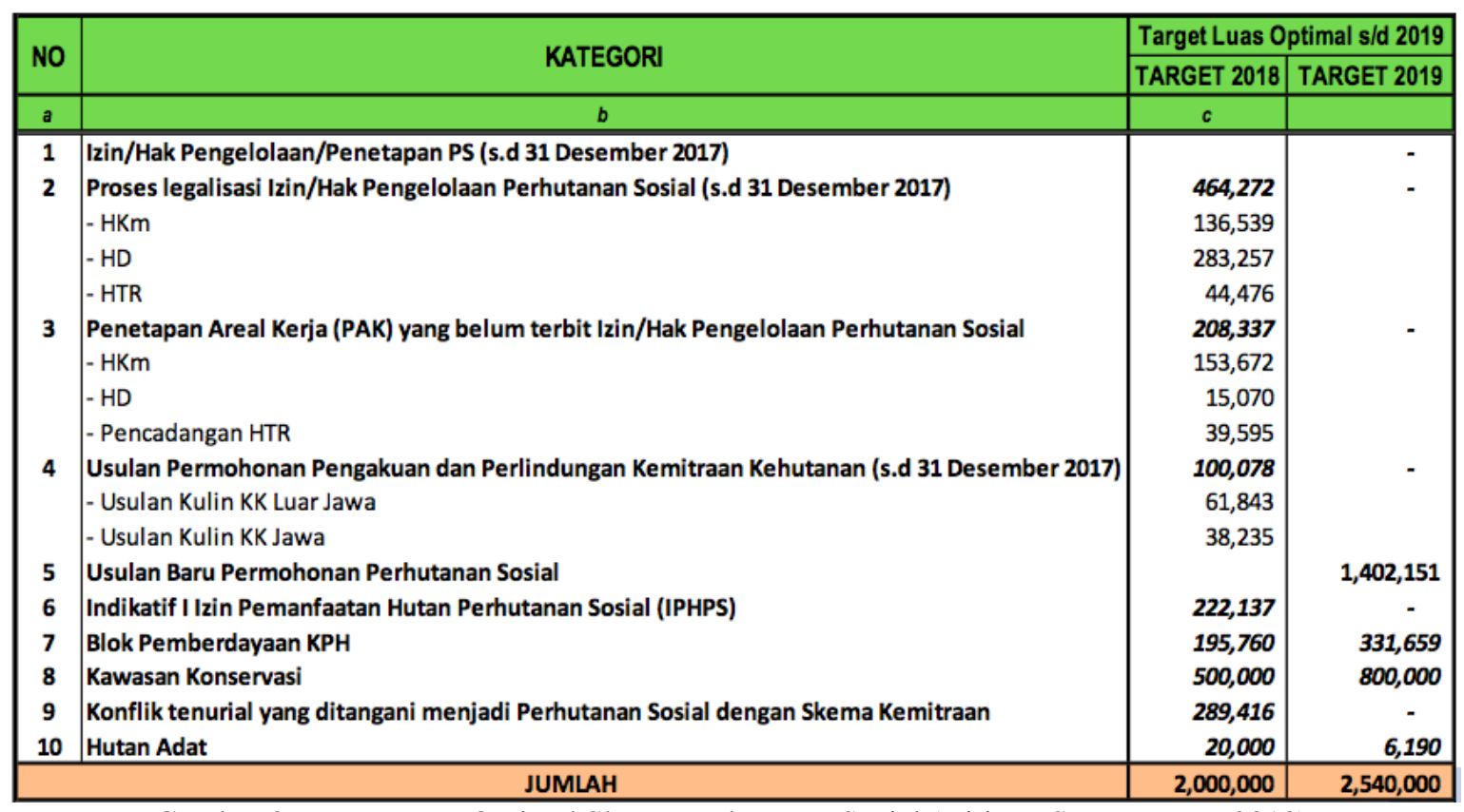

Gambar 3. Target Luas Optimal Skema Perhutanan Sosial (Ditjen PSKL-KLHK, 2018) 
Strategi percepatan pelaksanaan perhutanan sosial yang disiapkan oleh pemerintah, yaitu menyederhanakan peraturan yaitu PermenLHK Nomor P.83/Menlhk/Setjen/Kum.1/10/2016 dan turunannya, serta PermenLHK Nomor P.39/Menlhk/ Setjen/Kum.1/6/2017, menjalankan program Peta indikatif areal perhutanan sosial (PIAPS), dengan luasan \pm 13.462 .102 hektar untuk hutan desa (Hd), Hutan Kemasyarakatan (Hkm), hutan tanaman rakyat, kemitraan kehutanan, dan hutan adat, yang ditetapkan melalui SK.22/Menlhk/Setjen/PLA.0/1/2017,

melakukan monitoring dan evaluasi kinerja Kelompok kerja percepatan perhutanan sosial (Pokja PPS) dengan dasar Perdirjen Nomor P.14/PSKL/SET/PSL.0/11/2016, melaksanakan sistem navigasi perhutanan sosial, dimana akses kelola perhutanan sosial (AKPS) dapat dilihat secara online melalui halaman wesite resmi: http//pskl.menlhk.go.id/akps, dengan dasar Perdirjen Nomor P.15/PSKL/SET/ PSL.0/11/2016, dan melaksanakan Pilot project perhutanan sosial yaitu 16 lokasi pilot project perhutanan sosial (Himpunan Bank Milik Negara), dan 50 lokasi model perhutanan sosial Kemendesa PDTT (Ditjen PSKL, 2018).

Dampak dari kebijakan Perhutanan Sosial yang diharapkan antara lain untuk mengurangi kemiskinan melalui peningkatan pendapatan, penyediaan sumber ekonomi baru, peningkatan nilai tambah produksi hasil hutan, pengembangan unit usaha baru berbasis masyarakat, peningkatan investasi komunitas berbasis lahan (landscape), meningkatkan daya beli masyarakat/daya saing, dan mencipkatan industri dalam rangka meningkatkan ekspor. Selain itu kebijakan ini juga dimaksudkan dapat mewujudkan pengelolaan hutan lestari, mengurangi konflik tenurial, dan mengurangi pengangguran melalui

9

http://www.mongabay.co.id/2018/01/08/pengakuan penciptaan lapangan kerja baru di desa dari rantai bisnis produksi Perhutanan Sosial serta penyediaan tenaga pendamping di tingkat tapak kabupaten/kota/ provinsi/ pusat. Rencana umum Perhutanan Sosial menyangkut rencana strategis pengelolaan hutan mulai jangka pendek, menengah hingga 35 tahun ke depan, yang merupakan batas masa kelola Perhutanan Sosial. Sementara rencana operasional diantaranya menyangkut jenis atau tanaman dan komoditas apa yang layak dibudidayakan, metode dan manajemen pengelolaannya, pelestarian ekologisnya, rencana keuangan, pengembangan produk dan nilai tambah ekonomisnya serta pemasarannya.

\section{Akses Keadilan bagi Masyarakat di di Kawasan Hutan \\ Data Konsorsium Pembaruan}

Agraria, secara, tahun 2017 terjadi 659 konflik di berbagai wilayah Indonesia, dengan luasan 520.491,87 hektar, melibatkan 652.738 keluarga. Angka ini, alami kenaikan 50\% dibandingkan $2016 .{ }^{9}$ Pengukuhan kawasan hutan sejatinya merupakan bentuk kepastian hukum atas kawasan hutan, dimana seluruh proses yang harus dilakukan adalah penunjukan, penetapan batas, pemetaan dan penetapan kawasan hutan. Proses ini semua adalah untuk menuju suatu kawasan hutan yang "legal dan legitimate". Disatu sisi, masih banyak kasus akses lahan, masyarakat lokal dan masyarakat adat berada dalam posisi yang lemah dalam hal penggunaan sumber daya dan tenurial lainnya.

Dalam hal konflik tenurial, khususnya terkait masyarakat hukum adat (MHA), Undang-undang nomor 41/1999 tentang Kehutanan menyebutkan bahwa terdapat dua status hutan yaitu terbagi menjadi hutan negara dan hutan hak. Undang-Undang Kehutanan menjelaskan bahwa hutan negara dapat berupa hutan

-hutan-adat-minim-perlu-terobosan-pada-2018/.

Diakses pada tanggal 10 Desember 2018 
adat, yaitu hutan yang pengelolaannya diserahkan kepada masyarakat hukum adat. Selanjutnya, judicial review pun diajukan dan menghasilkan Keputusan Mahkamah Konstitusi Nomor 35 Tahun 2012, dimana hutan adat adalah hutan yang berada dalam wilayah masyarakat hukum adat (bukan lagi disebut dengan istilah hutan negara). Hal ini memberikan kelegaan terkait diakuinya hak-hak MHA untuk mengelola lahan/hutan sesuai kearifan lokal sekaligus menjaga kelestariannya.

Tantangan dalam pengakuan hutan adat adalah verifikasi dan perlu ada payung hukum, dalam hal mengurangi dan mengatasi konflik tenurial. Pemerintah telah menyiapkan dan mengimplementasikan beberapa Peraturan Perundang-Undangan, salah satunya melalui Peraturan Presiden Nomor 88 Tahun 2017 tentang Penyelesaian Penguasaan Tanah dalam Kawasan Hutan. Sedangkan dalam Peraturan Menteri Dalam Negeri Nomor 52 Tahun 2014 diatur tentang Pedoman Pengakuan dan Perlindungan Masyarakat Hukum Adat, dimana Gubenur dan Bupati/Walikota melakukan pengakuan dan perlindungan terhadap masyarakat hukum adat lewat pembentukan sebuah panitia yang melakukan identifikasi, verifikasi dan validasi masyarakat hukum adat.

Penyelesaian konflik di kawasan hutan berpedoman pada Peraturan Menteri LHK Nomor P.84/Menlhk-Setjen/2015 tentang Penanganan Konflik Tenurial
Kawasan Hutan, dimana penyelesaian konflik dapat melalui mediasi, Perhutanan Sosial, dan penegakan hukum. Dalam mengupayakan penanganan konflik tenurial dan hutan adat secara cepat, pemerintah telah menyediakan link pengaduan konflik tenurial serta usulan hutan adat. Dalam hal percepatan hutan adat, 17 unit SK Penetapan Hutan adat telah dikeluarkan dengan total luasan sebesar 21.917 Ha. Dalam hal akselerasi penanganan konflik, tenurial, dan hutan adat tahun 2017, pemerintah mentargetkan luas hutan yang bebas konflik tenurial, 270 ribu hektar sasaran kegiatan penanganan konflik tenurial masyarakat di kawasan hutan tercapai. Sedangkan untuk hutan adat, 25\% seluruh hutan adat dapat diidentifikasi, dipetakan dan ditetapkan pengelolaannya oleh masyarakat adat. Selain itu, sampai dengan awal tahun 2018, pemerintah telah menerima total luasan usulan wilayah adat seluas 1.369.344, 36 Ha, 195 diantaranya sudah disahkan (Ditjen PSKL, 2018). Dalam hal akses keadilan untuk mensejahterakan masyarakat Kawasan hutan, pemerintah pusat juga telah mengeluarkan beberapa kebijakan melalui peraturan perundang-undangan untuk dijadikan pedoman yang mendukung percepatan Perhutanan Sosial (Tabel 1). Tidak hanya pemeritah pusat, sudah sewajibnya pemerintah daerah melindungi dan mensejahterahkan keberadaan masyarakat kawasan hutan dengan mengeluarkan peraturan daerah maupun SK Bupati yang selaras dengan harmonisasi peraturan perundang-undangan diatasnya. 
Tabel 1. Beberapa Peraturan Perundang-Undangan dalam Dukungannya terhadap Perhutanan Sosial

\begin{tabular}{|l|l|l|}
\hline 1 & Permen LHK Nomor 28 Tahun 2015 & $\begin{array}{l}\text { Pedoman Umum Pengembangan Perhutanan } \\
\text { Masyarakat Pedesaan Berbasis Konservasi }\end{array}$ \\
\hline 2 & Permen LHK Nomor 29 Tahun 2015 & Pedoman Penyelenggaraan Kebun Bibit Rakyat \\
\hline 3 & Permen LHK Nomor 30 Tahun 2015 & $\begin{array}{l}\text { Pedoman Pemberian Bantuan Peralatan } \\
\text { Pengembangan Usha Ekonomi Produktif } \\
\text { Ramah Lingkungan }\end{array}$ \\
\hline 4 & Permen LHK Nomor 32 Tahun 2015 & Hutan Hak \\
\hline 5 & Permen LHK Nomor 34 Tahun 2017 & $\begin{array}{l}\text { Pengakuan dan Perlindungan Kearifan Lokal } \\
\text { dalam Pengelolaan Sumber Daya Alam dan } \\
\text { Lingkungan Hidup }\end{array}$ \\
\hline 5 & Permen LHK Nomor 39 Tahun 2017 & $\begin{array}{l}\text { Perhutanan Sosial di Wilayah Kerja Perum } \\
\text { Perhutani }\end{array}$ \\
\hline
\end{tabular}

Sumber: Kementerian Lingkungan Hidup dan Kehutanan, 2018

\section{E. Korelasi}

Merujuk pada data Badan Pusat Statistik tahun 2018, jumlah penduduk miskin (penduduk dengan pengeluaran per kapita per bulan di bawah Garis Kemiskinan) di Indonesia mencapai 25,95 juta orang $(9,82$ persen), berkurang sebesar 633,2 ribu orang dibandingkan dengan kondisi September 2017 yang sebesar 26,58 juta orang (10,12 persen). Rasio gini pada Maret 2018 adalah 0,389. Angka ini turun dari rasio gini setahun lalu, Maret 2017 sebesar $0,391 .{ }^{10}$

Sampai Juli 2018 capaian izin program Perhutanan Sosial seluruh Indonesia seluas 1,73 juta ha, melibatkan 384.753 keluarga tani. Pemberian izin Perhutanan Sosial di Jawa rata-rata sekitar 1,2 ha dan di luar Jawa rata-rata 3 ha. Program Perhutanan Sosial berdampak pada petani semakin percaya diri menjadi petani dan semakin bersemangat melaksanakan kegiatan produktif berbasis lahan. Semula petani di Jawa hanya memiliki lahan pertanian rata rata 0,3-0,5 ha per keluarga dan setelah adanya izin dari program Perhutanan Sosial lahan yang dapat dikerjakan petani meningkat menjadi 1-1,5 ha per keluarga.

10

https://www.bps.go.id/pressrelease/2018/07/16/148 3/persentase-penduduk-miskin-maret-2018-turun-
Kebijakan Perhutanan Sosial mampu menumbuhkan ekonomi domestik dan membuka kesempatan kerja terbuka luas. $\mathrm{HKm}$ telah membatasi hubungan antara petani dan tengkulak sehingga menggeser peran tengkulak sebagai patron semakin melemah, sedangkan petani yang sebelumnya menjadi klien memiliki otoritas lebih untuk mengelola perekonomian rumah-tangganya sendiri (Bayu,dkk. 2010). Keberadaan lahan HKm di Gunung Rinjani telah meningkatkan status ekonomi rumah tangga masyarakat hutan dari sekitar tingkat keseimbangan dasar (basic equilibrium level) yang setara dengan garis kemiskinan ke tingkat keseimbangan ekonomi yang lebih tinggi dan lebih sejahtera atau higher equilibrium level (Siddik, dkk. 2013). HKm Kalibiru dengan pola ekowisatanya mampu meraup pendapatan mencapai 5,9 milyar di tahun 2016, benchmark Perhutanan Sosial ini mampu menjelaskan terjaganya nilai ekologi karena SDA tetap terjaga dan tidak dieksplotasi, serta dilihat dari nilai sosial mampu meningkatkan kesejahteraan seluruh KTH dan masyarakat disekitarnya salah satunya melalui penyerapan tenaga

menjadi-9-82-persen.html. Diakses pada tanggal 4 Desember 2018 
kerja hingga tahun 2017 sejumlah 238 orang (Ditjen PSKL , 2018).

Benchmark lainnya yaitu dari data Ditjen PSKL (2018) peningkatan kesejahteraan masyarakat Kawasan hutan di Hutan Desa Pesisir Padang Tikar Kabupaten Kubu Raya, Provinsi Kalimantan Barat melalui Pola Agroforestry, dimana mampu menggerakkan bisnis dari hasil madu kelulut yang mencapai produksi perbulan $750 \mathrm{~kg} / \mathrm{bulan}$, dengan total penjualan 229.320.000/bulan. Sedangkan melalui pola sylvofishery, Perhutanan Sosial memberikan kesempatan yang sama dengan peningkatan kelipatan pendapatan saat ini mencapai 2,5 juta rupiah/bulan menjadi 40.098.124 juta rupiah/bulan (nilai diperoleh dari proyeksi 3 tahun kedepan dari proses pembelajaran keramba kepiting, budidaya lebah kelulut, pemanfaatan limbah arang batok). Data yang dihimpun dari operasionalisasi 63 Kesatuan Pemangku Hutan Produksi (KPHP) menyebutkan bahwa terjadi kenaikan pendapatan masyarakat yang menjadi mitra KPHP seperti dalam Gambar 4 dan Gambar 5 (Ditjen PHPL, 2018). Sedangkan potensi lapangan kerja yang dapat disediakan dari Perhutanan Sosial di dalam PIAS sejumlah lebih kirang 10,36 juta orang (Ditjen PSKL, 2018). Benchmark terkait legalitas hutan adat yaitu terbitnya SK Menteri Kehutanan No. 1152/MENLHK-PSKL/PKTHA-

PSL.1/3/2017 tanggal 16 Maret 2017 tentang Penetapan Pencantuman Hutan adat Tawang Panyai seluas 40,5 Ha yang merupakan sebuah kemenangan yang melegakan bagi masyarakat Hutan Adat Tapang Sambas-Tapang Kemayau dibawah gempuran perkebunan sawit (Ditjen PSKL, 2018). Tentu saja masih banyak benchmark Perhutanan Sosial yang lainnya, yang mampu menjelaskan bahwa kebijakan Perhutanan Sosial ini merupakan kebijakan yang patut diapresiasi dalam andilnya mengurangi angka kemiskinan di Indonesia.

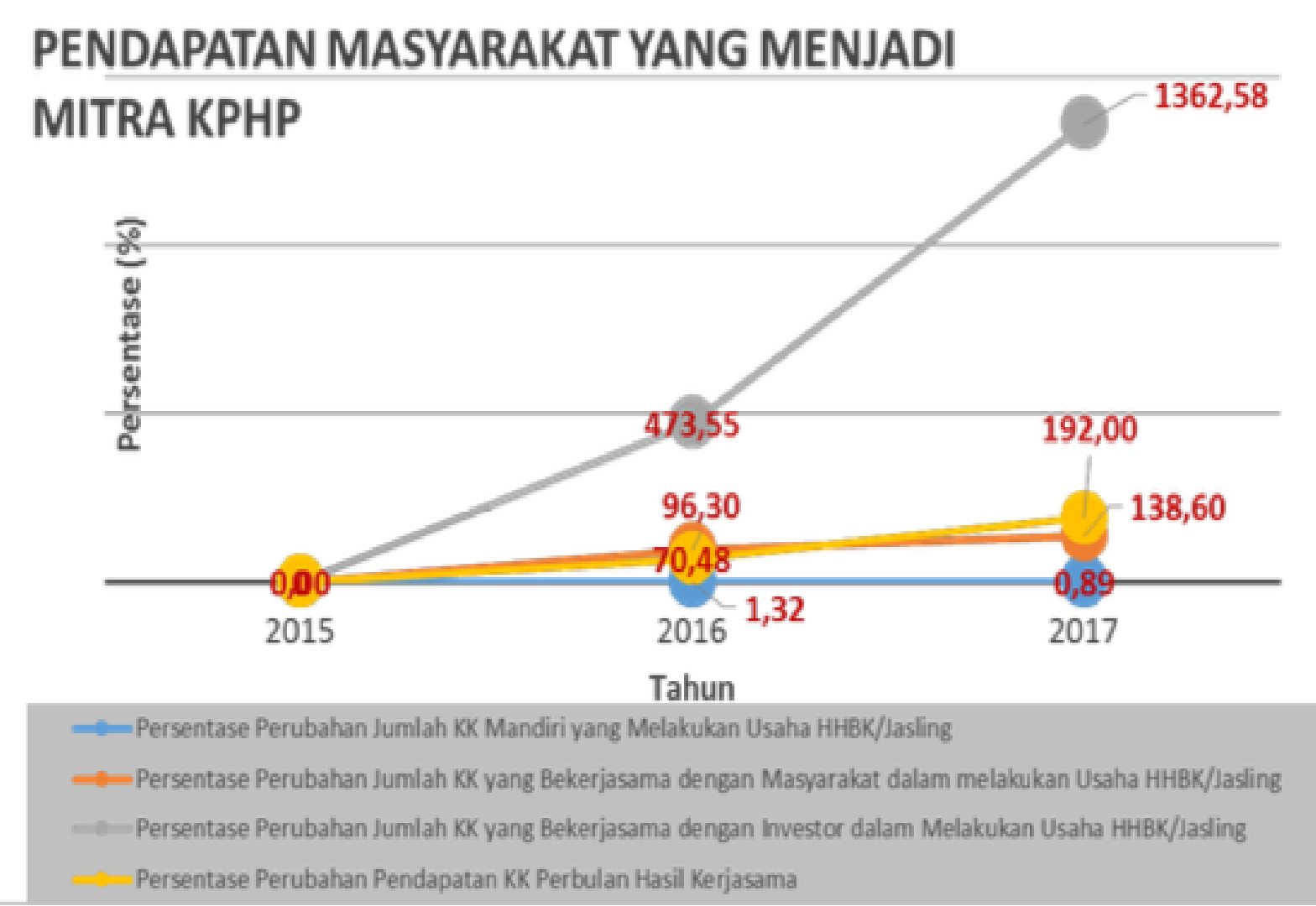

Gambar 4. Indikasi trend peningkatan pendapatan perkapita masyarakat yang menjadi mitra KPHP 

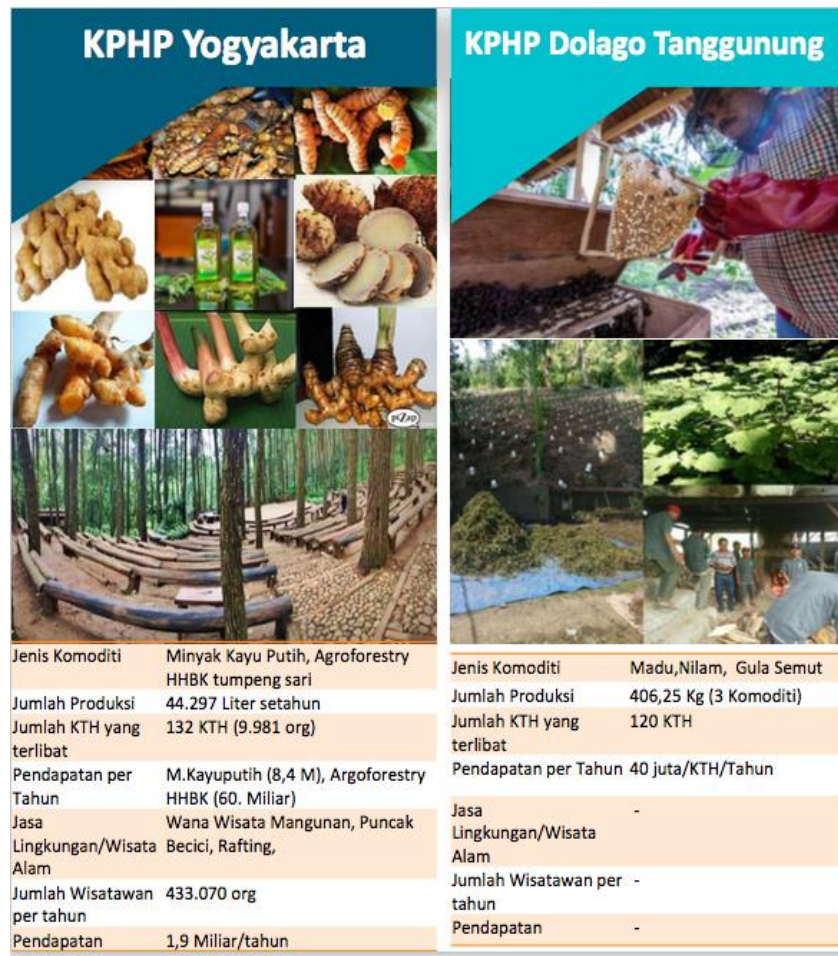
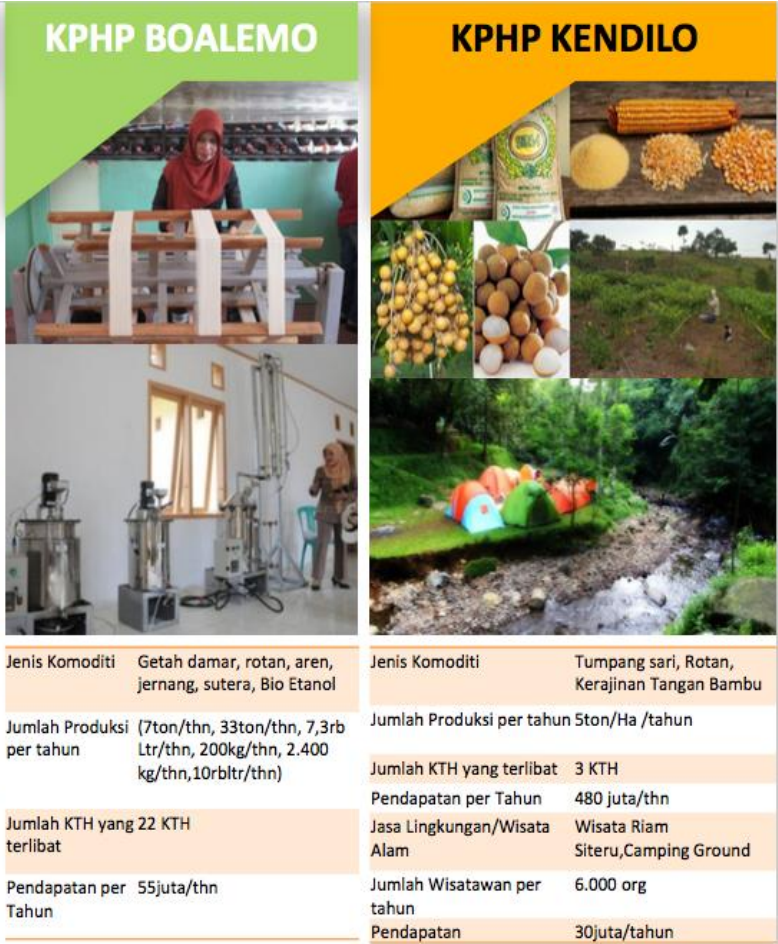

Gambar 5. Beberapa mitra KPHP

\section{F. Permasalahan dan Hambatan}

Ditegaskan oleh Kementerian Lingkungan Hidup dan Kehutanan (KLHK), bahwa Perhutanan Sosial bukan merupakan legalisasi deforestasi (Kompas, 2018). Kebijakan Perhutanan Sosial justru menginisiasi dan mengimplementasikan peran perlindungan hutan lestari sekaligus mengelaborasi masyarakat Kawasan hutan untuk berpartisipasi. Berdasarkan data yang dihimpun oleh KLHK tahun 2017, terjadi trend penurunan jumlah perambahan hutan,tingkat deforestasi dan jumlah hotspot di Kawasan KPHP (Ditjen PHPL, 2018). Kawasan hutan di Jawa dan Luar Jawa yang tak produktif akan ditanami ulang oleh masyarakat pemegang izin 35 tahun sehingga kawasan hutan tersebut menjadi lebih produktif, menghasilkan, memperbaiki lingkungan, pendapatan petani sekitar hutan meningkat dan kelembagaan petani menjadi kuat. 


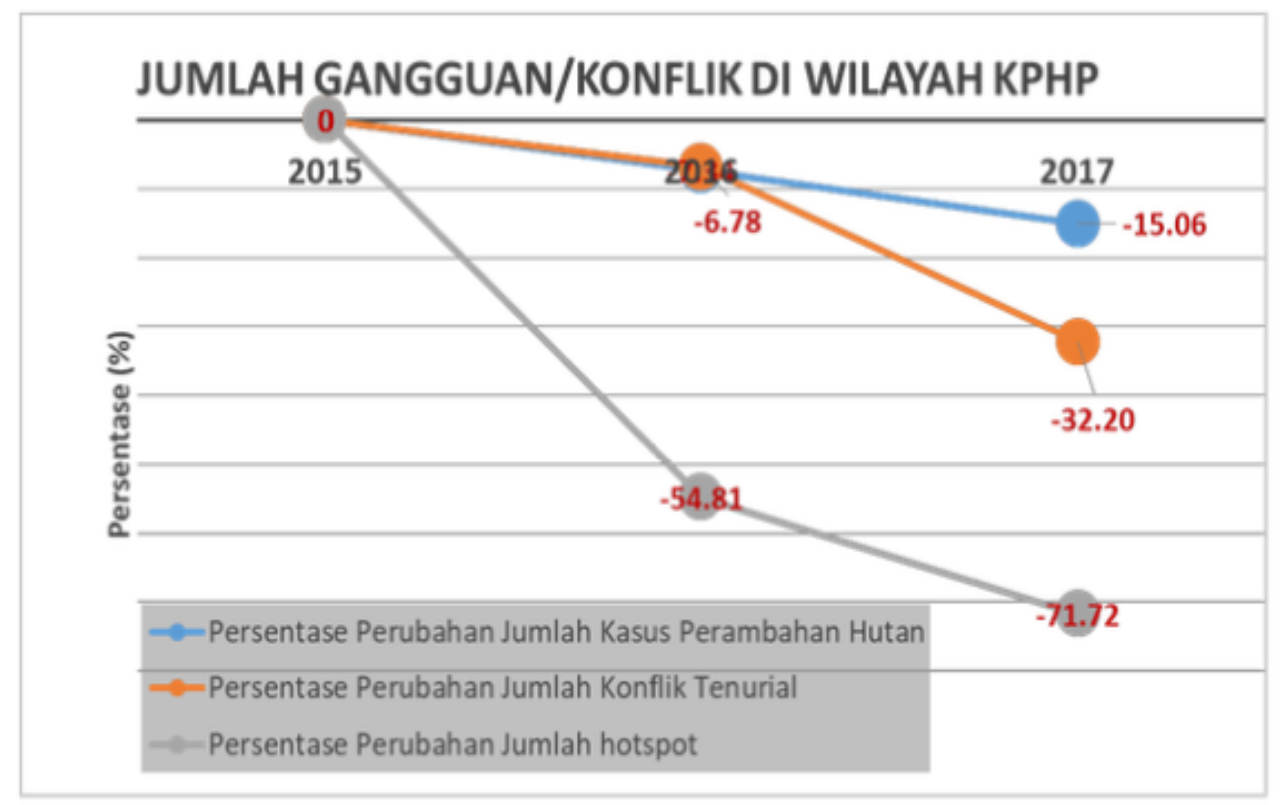

Gambar 6. Trend jumlah perambahan hutan, konflik tenurial dan trend penurunan kebakaran hutan, tingkat deforestasi jumlat hotspot di wilayah KPHP dan degradasi hutan di wilayah KPHP

Implementasi Perhutanan Sosial juga tidak luput dari beberapa hambatan yang terjadi. Beberapa hambatan yang dihadapi antara lain penyertaan masyarakat sebagai subyek dalam pengelolaan hutan masih belum efektif, adopsi teknologi tepat guna masih rendah, daya saing produk rendah, industri pengolahan belum ke arah high end product dengan nilai tambah tinggi, serta tekanan sosial dan masalah kemanan masih tinggi. 11 Kayu hutan kemasyarakatan mempunyai kualitas lebih rendah dari kayu hutan alam. ${ }^{12}$ Masih terdapat hambatan pengelolaan produk Perhutanan Sosial dari rantai pemasaran menyebabkan timbulnya distribusi keuntungan yang tidak merata. ${ }^{13}$ Perizinan 35 tahun program Perhutanan Sosial dan dapat diperpanjang secara nyata telah memberikan tambahan luas areal lahan yang dapat dimanfaatkan untuk kegiatan usaha kehutanan dan usaha pertanian, perkebunan, buah-buahan dan tanaman semusim palawija. Disamping perizinan, pemerintah memberikan insentif ekonomi seperti bantuan permodalan, akses

\footnotetext{
${ }^{11}$ Ditjen PHPL, 2018

${ }^{12}$ Muslich dan Rulliaty, 2010.
}

pasar, dan pendampingan yang dikelola secara klaster.Namun, tahap yang sangat menentukan adalah bagaimana kemampuan masyarakat dalam mengelola sumber daya hutan.

\section{G. Kesimpulan}

Perhutanan Sosial yang dijalankan melalui pemberian akses pengelolaan hutan kepada masyarakat di dalam dan sekitar kawasan hutan merupakan kebijakan yang patut diapresiasi yang secara nyata meningkatkan kesejahteraan masyarakat Kawasan hutan, mempercepat pembangunan perdesaan, memutus lingkaran kemiskinan dari akarnya, yang pada akhirnya bermuara pada penurunan angka kemiskinan.

\section{H. Rekomendasi}

1. Untuk meningkatkan kemampuan masyarakat Kawasan hutan, Pemerintah perlu terus mendorong dan memberikan instrument fiskal baik berupa bantuan maupun

\footnotetext{
${ }^{13}$ Effendi, Rachman. 2010.
} 
insentif ekonomi terhadap peningkatan akses terhadap informasi, keterampilan, teknologi tepat guna, pendampingan, pelatihan dan pengembangan produk, penanganan pasca panen, pemasaran komoditas dan produk, untuk membantu partisipasi masyarakat lokal dalam pasar, meningkatkan produktifitas dan nilai tambah, memperoleh rantai pasar yang efisien, distribusi keuntungan produk yang adil, serta perolehan manfaat yang lebih banyak.

2. Dalam hal percepatan Perhutanan Sosial, Pemerintah perlu membuat instrument kebijakan perencanaan dan penganggaran percepatan perhutanan sosial yang dianggarkan melalui APBD Provinsi, memperluas cakupan penggunaan Dana Alokasi Khusus (DAK) sub bidang kehutanan untuk penyediaan fasilitas kegiatan pendampingan dan pengembangan perhutanan sosial, serta mensinergikan program dan kegiatan pemerintahan desa yang di danai melalui Dana Desa (DD) untuk kebutuhan memfasilitasi penyiapan areal dan pengembangan hutan desa.

3. Pemerintah perlu meningkatkan sinergitas Program/kegiatan antar Kementerian/Lembaga terkait (Kemendesa PDT Trans, BUMN, Kementerian Koperasi dan UKM, Kementerian Pertanian, Kementerian Kelautan dan Perikanan) dan penguatan peran pemerintah provinsi, serta sinergitas dengan perhutani.

\section{Daftar Pustaka}

\section{Buku}

Awang, San Afri. 2007. Poltik Kehutanan Masyarakat. Jogjakarta: Kreasi Wacana

\section{Dokumen}

Badan Penyuluhan dan Pengembangan Sumber Daya Manusia (BP2SDM). 2018. Peran BP2SDM untuk Percepatan Keberhasilan Perhutanan Sosial di Tingkat Tapak. Rapat Koordinasi Teknis Reforma Agraria dan Perhutanan Sosial. Kementerian Lingkungan Hidup dan Kehutanan.

Direktorat Jenderal . 2018. Reforma Agraria dan Perhutanan Sosial pada Hutan Produksi. Rapat Koordinasi Teknis Reforma Agraria dan Perhutanan Sosial. Kementerian Lingkungan Hidup dan Kehutanan.

Direktorat Jenderal Konsevasi Sumber Daya Alam dan Ekosistem (KSDAE). 2018. Reforma Agraria Perhutanan Sosial di Kawasan Konservasi. Rapat Koordinasi Teknis Reforma Agraria dan Perhutanan Sosial. Kementerian Lingkungan Hidup dan Kehutanan.

Direktorat Jenderal Perhutanan Sosial dan Kemitraan Lingkungan. 2018. Pengentasan Kemiskinan melalui Perhutanan Sosial. Rapat Koordinasi Teknis Reforma Agraria dan Perhutanan Sosial. Kementerian Lingkungan Hidup dan Kehutanan.

Direktorat Jenderal Perlindungan Daerah Aliran Sungai dan Hutan Lindung (PDASHL). 2018. Pembangunan Bidang PDASHL dalam Mendukung Program Reforma Agraria dan Perhutanan Sosial. Rapat Koordinasi Teknis Reforma Agraria dan Perhutanan Sosial. Kementerian Lingkungan Hidup dan Kehutanan.

Direktorat Jenderal PHPL. 2018. Pengentasan Kemiskina di Tingkat Tapak melalui Rekonfigurasi Bisnis Kehutanan.Kementerian Lingkungan Hidup dan Kehutanan.

Effendi, Rachman. 2010. Rantai Pasar Produk Social Forestry, Social Forestry Hal 109-119. Badan Penelitian dan Pengembangan Kehutanan. Kementerian Kehutanan 
Muslich dan Rulliaty, 2010. Kualitas Kayu Produk Social Forestry. Social Forestry. Hal 121-132. Badan Penelitian dan Pengembangan Kehutanan. Kementerian Kehutanan.

Sunderlin, W.D., Resosudarmo, I.A.P., Rianto, E. dan Angelsen, A. 2000. The effect of Indonesia's economic crisis on small farmers and natural forest cover in the outer islands. Occasional Paper 29(E). Bogor, CIFOR.

Warner, K. 2000. Forestry and sustainable livelihoods. Unasylva 202, Vol. 512000/3. FAO, Rome.

\section{$\underline{\text { Website }}$}

http://www.worldagroforestry.org/sea/Publ ications/files/report/RP024108/RP0241-08-2.pdf. Diakses pada tanggal 4 Desember 2018

http://www.perhutani.co.id/2018/11/pemer intah-terbitkan-37-izin-pemanfaatanhutan-sosial-oleh-masyarakat/.

Diaskes pada tanggal 4 Desember 2018

https://kompas.id/baca/opini/2018/07/17/p erhutanan-sosial-sebagai-legalisasideforestasi/. Diakses pada tanggal 4 Desember 2018 